\title{
Gendered Selves Reconstruction in Alice Walker's The Color Purple and Maya Angelou's I Know Why the Caged Bird Sings
}

\author{
Blossom Shimayam Ottoh-Agede ${ }^{1, *}$ \\ ${ }^{1}$ Department of English, Federal University Lafia, Nasarawa State, Nigeria \\ *Correspondence: Department of English, Federal University Lafia, Nasarawa State, Nigeria \\ Tel: 234-806-382-8763Ｅ-mail: blofem@yahoo.com
}

Received: April 5, $2013 \quad$ Accepted: April 26, $2013 \quad$ Online Published: June 9, 2013

doi:10.5430/wjel.v3n2p22 ～URL: http://dx.doi.org/10.5430/wjel.v3n2p22

\begin{abstract}
Research in diverse fields as anthropology, linguistics, psychology, sociology, history, literature, gender studies, and social theory, among others, has firmly established the fundamental role of society in the formation and establishment of gender identity, but fails to indicate the causative roles of individuals in constructing gender and self identity. Most gender scholars avoid the simple truth that gender roles are more of self ascription than societal. The society is not a person but persons who come together with a common language and culture. This paper explores the creation of self and gender identity in Alice Walker's The color purple and Maya Angelou's I know why the caged bird sings. The investigation pictures the ways Walker and Angelou negotiate, manipulate and reconstruct the Black-female identity. We discover that Walker and Angelou espouse a feminist and xenophobic approach to represent the female-story by portraying first, a treble victimization and then the subsequent victory of their Black-American female protagonists. The study attempts to show how their deployment of linguistic properties communicates the female self in a Black-American community and concludes that individuals are the architects of their lives. We adopt the [Feminist] Standpoint and Social Identity theories for analysis of texts.
\end{abstract}

Keywords: feminism; patriarchy; social construction; stereotyping; treble-victimization

\section{Introduction}

Many scholars have presented papers, written articles on gender and its social construction. Talk shows presenters like Oprah Winfrey, the Nigerian talk show, Moments with Mo and many others have offered their perspectives. They give valid reasoning as they invite notable and well respected personalities to the debate, most of all, their presentations thrive. And more importantly is the newsworthy issues, "gender and gender roles".

Also, diverse research in fields such as psychology, sociology, anthropology, history, literature, gender studies among other social theories, has strongly persuaded us on the essential role of society in constructing and establishing gender identity. And in recent years, the study of gender and gender issues have become trends and even so perilous adventures where scholars who have embarked on them, have successfully navigated between instituting them as socially constructed observable facts than just mere self construct. For instance, the sociologist, Gupta (2000), sees gender as socially and culturally defined, Feldman (1996), a psychologist, also views gender as a social creation; a gender scholar, Wood (1999) argues that gender is not only socially constructed, it is socially enacted too. Although these scholars argue in line with my perspective, I also view gender roles as a self construct which suggests that the individuals who operate them are not naïve of their creation.

More so, there have been different debates on the fact that the society is the sole influencing factor of gender role formation which therefore makes the society the god of the genders. The god in the sense that it determines which gender does what, where it does it, even when it does it, and who becomes what. But the fact is someone cannot become a god to something s/he did not create. Moreover, in this paper, I agree that although the society is a determining factor in administering gender roles, my standpoint differ in some respect, in that, while gender roles have been a social construct, the individuals who operate them are not completely naive of its creation and enactment. This is so because many victims of gender discrimination have themselves been the facilitators of its endorsement. 
Let us take the female folk for instance; it is the woman who victimizes the woman, hence the popular cliché, "victim victimizing a victim". The woman is the instrument of oppression on her fellow woman. Unlike the African literature, where African literary writers present the mother-in-law and the "other woman", who could be a concubine or a co-wife as the 'devil' that bewitches the wife (the victim), the African American female writings that I explore in this paper, presents the woman as a reassuring agent, a helper to her other woman. African American female writings most times see the 'other woman' as a victim and a co-sufferer in the world of men, and so to succeed they collaborate and fight as fellow victims in a patriarchal society.

\section{Theoretical Orientation}

The standpoint theory began with Georg Wilhelm Friedrich Hegel's reflections on the institute of slavery. Hegel (1807), an outstanding $19^{\text {th }}$ century German philosopher, posits that the society as a whole recognizes that slavery existed, but that the nature of the institution was perceived quite differently depending on whether one's position was that of master or slave (Wood, 1999:58-9). For Hegel, in any society where power relationships exit, there can be no single perspective. Different opinions emerge according to different standpoints. Everybody sees the society only as it appears from his/her social perspective. This is the reason the theory is known as Standpoint Theory. Harding (1991:59) argues that those in positions of high power have a vested interest in preserving their place in the hierarchy, so their views of social life are more distorted than those of the person(s) who gain(s) little or nothing from the existing power relations.

Hence, the standpoint theory is a contribution from the cultural perspective which argues that a person's position is influenced by the person's location. That is to say that, a person's location within a culture could shape or mold his or her life likewise a person's position within a particular gender could also influence or serve as leverage to his/her perspective. This theory brought about the feminist conjecture which became the feminist standpoint theory in the 1970s.

The feminist standpoint theorists believe that, there are relations between socio-political power and knowledge. The theory describes and analyzes the causal effects of power structures on knowledge and at the same time advocates for a specific method of enquiry. The theory also holds that, marginalized perspectives can inform all of us about how our society operates. The social identity theory is also important to this analysis because in the past, to a large extent, in response to postmodernist thinking, social identity theory stressed individual choice and/or free will, and subjective reasoning which question any imposition or unnecessary interference on human thoughts.

A well known philosopher, Roberto Mangaberia Unger who revised classical social theory, explored the connection of structures in society, and examined how things fit together, and rather than providing an all encompassing single explanation to universal reality, Unger indicates classical social theory of society as an artifact. He argues that "classical social theory was born proclaiming that society is made and imagined, and not the expression of an underlying natural order, but at the same time its capacity was checked by the equally prevalent ambition to create law-like explanations of history and social development" (Unger, 1987). Social identity theory seeks to explain change in society; it shows how it develops, what factors facilitate and inhibit it, and what results from it. It is very apt to my discussion here because it brings us to the point I earlier made, that when we say society, it not an individual or a person. But that society is made and imagined by men.

\section{Black Female Literatures and Autobiographies}

African American literature had started long before the Harlem Renaissance of the 1920s and 30s with the oral performances which provided some relief for African American slaves, whenever possible, from the physical and psychological horrors of their lives. Although these oral performances went on through the $17^{\text {th }}$ century, the written literature did not emerge until the $18^{\text {th }}$ century, principally because slaves were forbidden to acquire literacy or were not allowed to be involved in any intellectual exercise that might engineer or ginger a rebellion against their masters.

However, gradually, writing began to emerge, and the earliest forms came from the Northern and Eastern states where slaves had a modicum of educational exposure. Some of these writers are Lucy Terry who wrote a verse entitled, 'Bars fight, August 28, 1746' (1746), Jupiter Hammon who wrote 'An evening thought: salvation by Christ, with penitential cries' (1760). There were also Phillis Wheatley's poems on 'Various subjects, religious and moral' (1773); a collection of elegies and devotional lyrics (Killam \& Rowe Eds. 2000:214).

For Baker (1971:401), from the $18^{\text {th }}$ century when writing increased among African Americans, much of it consisted 
of real-life accounts of ex-slaves and fugitive slaves which were supported by the abolitionist movement. Examples of these slave writings are: Olaudah Equiano's Interesting narrative of the life of Olaudah Equiano, or Gustavus Vassa, the African Written by Himself (1789), Frederick Douglas's autobiography, Narrative of the Life of Frederick Douglas, an American Ex-slave (1845), and so on. However, the $19^{\text {th }}$ century was characteristic of a new consciousness and a succession of novelists and playwrights who painfully forged the literary tradition that expressed the dilemma that arose from the recognition of their African heritage, and at the same time portrayed their American destiny. In their writings are anger, self-assertion and indictments of historical wrongs which are intermingled with a desire for acceptance by the dominant White culture.

Moreover, for the female writers, similar themes were explored in the context of the quest for gender and self identity and acceptance in the society that resolutely denies the African American female reality. Common themes run through their literatures, whether urban or rural, northern or southern. Generally, black autobiographies, literature, music and folklore express dispossession and protest, oppression and invisibility, achievement and survival, wholeness and fulfillment, most of all, there was a search for that which was lost - racial, gender, personal/cultural and even linguistic identities.

Consequent upon this search for self identity, the African American women writers from their experience of being treble-victimized as Blacks, as females and as Black women brought invaluable female perspectives to their portrayal of the female gender as a significant being, and other human experiences in their texts. The point to also note is that, the contemporary Black female writing, stresses gender contradictions, incestuous rape and other forms of male-on-female violence in their texts.

The African American female writer, from the beginning of the time when women started writing, saw writing as one way to enact history and redress her story, first and foremost as a black["man"] and then as a human woman. Story telling as an African activity was embraced by most African Americans as a way of purging their emotions on the one hand, and seeking victory on the other. Thus, Black female literature evolved and the key for the woman writer since then is the word "search" which suggests, scrutiny, attention, mindfulness, intentness, thought, observance all to the intent of recovery of that which was lost (see Eko, 2005:1).

Eko (2005) is of the opinion that women artists in America are naturally in the vanguard of using their arts in creative responses to cultural, social and historical pressures. In congruence to Eko's opinion, we posit that the Black woman artist in the face of gender discriminations in America, seeks to redress the female story by asking the question what happened to the Black and female side of the wonderfully, just, right and God-given mandate to equal enjoyment of freedom for everyone.

Over the centuries, male dominance has engendered woman's inferiority complex, voicelessness, traumatic experience and negative self-perception. But today, African Americans, the women in particular, find outlets in the outcry of their female protagonists: from Sojourner Truth's fearless challenges and affronts to Jeanie Stark's resistance in Their Eyes Were Watching God by Zora Neale Hurston, to Maya Angelou's triumph in I Know Why the Caged Bird Sings, and to Alice Walker's female protagonist's (Celie's) courage in The Color Purple.

Most importantly, the Black feminist literature emerged as a literature of self-assertion, self-definition and has grown by negotiating the cultural taste within the dominant Euro-American culture. In sum, Black consciousness naturally lent itself to the expression of creative/cultural activity, gender reconstruction, etc. such that cultural and self revivals were the agenda of Black American women literary investigations and literary writings as a whole.

\subsection{Walker's and Angelou's Texts at a Glance}

The Color Purple is an epistolary realism written by Walker about Celie, a female protagonist, who is located in the $19^{\text {th }}$ century tradition of the African American women. Celie, a poor, uneducated Black woman writes letters that illustrate her poignant attempt to make sense of her oppressed life. She has been sexually abused by her stepfather and later she is married off to an older man, Albert. She becomes strong by meeting and learning to love Shug Avery, who is Albert's mistress. Celie becomes awakened when Shug packs in to live with her and Albert. This is when for the first time in her life, Celie experiences love (see Taylor, 1992).

For years, Celie writes to God. Her sister, Nettie, also writes to her recounting her missionary activities in Africa, but Celie never gets them because Albert intercepts the letters. But along the line, Celie discovers the letters Nettie had been sending to her, a discovery that is the catalyst for her self-actualization, as she becomes angry with Albert for depriving her, and also making her live a regimented life. She later leaves Albert to live with Shug, where she becomes a self-empowered woman who fends for herself by making pants. Because of her healing and internal growth, Albert learns to value her as a human being, and also asks her to return to him. Celie's children from the 
beginning of the novel are sold off by Pa, her stepfather. But the novel ends on a note of celebration as most relationships are healed, families reunited. Celie reunites with her sister and children. She is a round character, who develops with time.

Several other women in the text are engaged in similar self-actualizing journey, either as guides or as learners. Sofia is one of such women; she is a guide, and a very intractable and determined woman. She returns blow for blow whenever Harpo, her husband tries to overawe her. She breaks herself out of entrenched chauvinism and dehumanization. Her love for Harpo suddenly dies when she discovers that sex and marriage are euphemisms for male dominance and control. She finally recovers, but not without a permanent scar left by the male oppression.

On the other hand, men in The Color Purple are not celebrated. Walker characterizes the male characters as lazy, selfish, insensitive, abusive and unkind. This is the reason why Celie refuses to call Albert by his name, she rather prefers to call him Mr.- , which also suggests Celie's initial fear of the man and the need to create and maintain an emotional distance.

Maya Angelou in I Know Why the Caged Bird Sings, exposes the pervasiveness of racism and gender discrimination in American life. She recalls her encounter in Stamps, Arkansas- a Black segregated area in the southern part of America. Angelou, who is known as Marguerite and the narrator, expresses her life's experiences from childhood to adulthood. The text is set in Stamps, and partly in St. Louis and California. It is an autobiographical novel, a first person account of a three year old Marguerite and other people close to her, like her older brother, Bailey for whom Angelou shares most of her world, Momma- Annie Henderson, whom she spends her childhood with in Stamps and Uncle Willie, their cripple uncle, her father’s (Bailey Sr.) brother (Hillmann, 1992).

The text, I Know Why the Caged Bird Sings, is an astute piece depicting an American rural Black community in the 1930s and its worldview. As children, Angelou and Bailey visit their mother, Vivian Baxter in St. Louis, where the Baxter family live. Their mother, Vivian is a club dancer and has a live-in-lover, Mr. Freeman, who rapes Marguerite at age six, and is killed by one of Marguerite's uncles in the process of the narration. According to Onwuegbuche, Eko and Mogu (2009), Vivian Baxter, Angelou's mother, "cuts a different image to the other mother substitutes like Momma Henderson, Mrs. Bertha Flowers and even grandmother Baxter". For these writers, "Vivian Baxter's role in the growth of her daughter in the text does not show motherhood but instead, abandonment, a crime their father Bailey Sr., was culpable of too".

In Angelou's view, Vivian Baxter's beauty forbids her from having children which is her reason for sending them away in the first place (see Onwuegbuche et al., 2009). In the same vein, McPherson, (1990:38-39) observes that, "Angelou's mother, like their father, Bailey Sr. represents some distant world unknown to Maya, Vivian Baxter's world is equally foreign as she expresses boldness, self reliance and remains very unconventional". Although Vivian Baxter is trained as a nurse, she provides for her children by dancing in night clubs couple with her association with her live-in-lover, Mr. Freeman. In his view, Demetrakopoulus (1980:198) argues that, "for Mr. Freeman, who is always in the house waiting for his woman, who is not [always available], Angelou became a stop-gap, which he uses as an extension of the mother to assuage his denied sexual urge”, an action that exploited an eight year old girl's virginity and personhood, and eventually ushers in crisis in the young girl's life.

On her return to Stamps, Marguerite mopes around in sullen silence for over a year being an after effect of the rape, but with the help of the sophisticated and sympathetic Mrs. Flowers, she finds direction and self pride. Mrs. Flowers is a White woman admired by Marguerite, so helping her to regain her speech is a thing of honour to Marguerite. Mrs. Flowers is one woman that Angelou claims "was one of the few gentlewomen I have ever known and has remained throughout my life the measure of what a human being can be" (I Know Why The Caged Bird Sings, p. 78). Fox-Genovese (1990:223) also posits that, the character of "Mrs. Flowers joined the world of Stamps to the world of literature, embodied in her person the dreams that shaped Marguerite's imagination. For Marguerite, under Mrs. Flower's tutelage, formal education became salvation”. Mrs. Flowers most importantly teaches Marguerite to recognize and appreciate the beauty of black culture (see Onwuegbuche et al., 2009:16)

At fifteen years, she worries about the possibility of becoming a lesbian hence Marguerite decides to have sex with a handsome man, living in the neighborhood. This experience leaves her with a long lasting legacy, as she becomes pregnant and later delivers her son, Guy for whom she finds peace. Her memories of sleeping peacefully with her son bring the narrative to a close. Angelou finds meaning and special value in unvarnished memories of difficult times and imperfect people. She loves her race and gender, in spite of the masochistic attitudes other Black women exhibit. She possesses an inner strength as a result of her Black heritage and experiences as a Black female.

In sum, as Black female activists, Angelou and Walker out-rightly reject the ill treatments that the society, which is 
dominated by men, inflicted on the woman in America. As their novels, however, portray, through their female characters' use language, there is a recreation and/or reconstruction and establishment of gender identity that is enthused by the image of the other woman in their lives. The women in the lives of Celie and Marguerite changed their perspective about men. While Celie has Nettie, Shug and Sofia as her stimulants, Marguerite, on the other hand, has Mrs. Flowers as her inspiration.

\subsubsection{The Journey to Gendered-selves Reconstruction}

In The Color Purple, Celie, Walker's protagonist's personal trauma from a disastrous marriage and separation from her children is trebled by her separation from her sister, Nettie. Marguerite, in Angelou's The Caged Bird, also experiences displacement as she journeys from Stamps to San Francisco to California and then back to San Francisco, a journey that explains her life from naivety through maturity to self-empowerment and self-assertion.

Maya Angelou's nationalistic novel, I Know Why the Caged Bird Sings and Alice Walker's The Color Purple both express the Black-female consciousness by indirectly testifying to the resilience of the authors who prevailed over personal adversity to become the muse of many women in the African American female literature. Both Angelou and Walker, moreover, project protagonists whose search for a home crisscrosses with their history of the Black American displacement and dispossession.

In the course of her displacement, having stayed with a grandmother in a small town of Stamps, Marguerite (Angelou) becomes self-actualized as she moves from innocence to maturity. This displacement of moving from one place to the other does not only bring her to maturity, but also teaches her to face life's challenges without the help of her brother, Bailey. The experience in the car lot where she stays for a month with other homeless children also exposes her and teaches her resilience and strength, so that, the soft-hearted 'Sister' that Momma knows develops and grows to become a strong-willed Maya. This encounter helps her and makes her able to get a job in a white establishment that is a restricted area for the whites only. She then later becomes the first Negro conductorette, a lady car conductor on the San Francisco streetcar (The Caged Bird, p.262).

In consonance with other female writings, African American female writers demonstrate a collective consciousness of the black woman's predicament in America. The dilemma for the black woman was a world subjugated by patriarchy.

\subsection{Angelou and Walker on Gender Identity}

Collins (1986) using the standpoint theory argues that Black American scholars generally have special insights into the Western culture because of their dual positions or standpoints as outsiders within or as members of a minority group (African-American) in a dominate white (American) culture. Like we stated earlier, everyone occupies a standpoint that overlaps and interacts whether you know it or not. On this note we can say that, the identity of Angelou and Walker's protagonists (Celie) as African- American females is shaped by both race and gender standpoints.

Angelou displays the victimization of the woman in her novel as she says, "the Black female is assaulted in her tender years by all those common forces of nature at the same time that she is caught in a tripartite crossfire of masculine prejudice, white illogical hate and Black lack of power" (p.265). Hillmann (1992) argues that, that "masculine power is what makes her narrative as autobiography all the more telling”. In Hillmann's view, the text, $I$ Know Why the Caged Bird Sings, figures prominently in at least three contexts: in women's writing generally, in the literature of the American Black experience, and in its significance as an autobiography.

Moreover, Angelou brings into the novel a rich and varied vocabulary, a feeling for the rhythms of speech, and a fertile imagination to bear on the slightest recollection from her childhood. For Hillmann, Angelou's metaphor and simile, which almost invariably communicate the richness of her family and community environment and the Black American culture of which they are part, are especially engaging. He also claims that, Angelou relates events from the perspective of the middle-aged adult that she was when writing, but she gives them the flavour and personality of a child experiencing them (Hillmann, 1992:217).

Several critics have also examined Walker's writings. Taylor (1992:107-110) posits that Alice Walker's text, The Color Purple is written in the vernacular used by poor southern Blacks. As an epistolary realism, the letters convey not a self-righteous parceling out of blame and judgment on Walker's part, but a genuine, empathetic search for love and meaning in life. Taylor describes Walker's novel as a book that shows Black feminism as compatible with good fiction.

Different scholars hold different views. There is a perspective that holds that Alice Walker's text offers a 
concentrated vision of the experiences of the Black in female Diaspora, and these experiences are recounted to display the enduring qualities of dignity and industry, strength and survival and the fight against oppression from the man. The experiences also explain the position of importance the female protagonist often plays in terms of her initiative and dynamism, a dynamism which is characterized by the Black woman's ability to transcend the roles and attributes accorded her by patriarchy.

Moreover, a significant feature of Alice Walker's writing is her openness to exposing personal experiences. She has been commended by critics for her natural quality of authority and her assurance with words. In her works, many connections can be made between her life and those of her characters. Thus, her emotional intimacy with her creations animates her work for the new reader. Walker's subject matter ranges from history to everyday life, and to spirituality. She explores themes like abortion, sadomasochism and rape, all of which are described bluntly. She has been criticized by most African American critics for dealing harshly with her Black male characters.

In sum, confronting racist and patriarchal systems, Walker and Angelou envisage a world of justice, equity and fair play in a society of men and women, White and Black, using their texts as moral as well as artistic documents on a mission.

\subsection{The Image of the 'Other' Woman}

Patriarchal system is often characterized as alienating, dehumanizing and without proper commitment to the female gender. Man's hegemony makes the woman to feel unsafe and demoralized. The male gender has employed the other woman as instrument of oppression on the female. For instance, from the excerpt below we see the picture of the other woman at play as Celie trembles and writes:

Dear God,

Shug Avery was a woman. The most beautiful woman I ever saw. She more pretty then my mama. She bout ten thousand times more prettier then me. I see her tere in furs. He face rouge. Her hair like somethin tail she grinning with her foot up on somebody like motocar. Her eyes serious tho. Sad some. I ast her to give me the picture. An all night long I stare at it. An now when I dream, I dream of Shug Avery. She be dressed to kill, whirling and laughing (The Color Purple, p. 16)

Very often the man uses the other woman as a symbol to punish the woman in his life. Celie suffers insecurity looking at the text above. Husbands and the male gender generally deploy the other-woman as an instrument for punishing and afflicting his victim, the wife, as he makes the woman to imagine he is invincible. On the other hand, Shug Avery, a self-confident character, who represents the symbol of the "other woman" in the text, a mistress to Mr. Albert, believes that only when the woman thinks of the man as being ubiquitous, that the man assumes an oppressive-god-status; a view that is also buttressed in the Third wave feminist thinking pioneered by Naomi Wolf (see Wood, 1999). Shug enjoins Celie not to believe that man is everywhere, that as soon as Celie begins to assume that man is everywhere, then she will begin to see man as God. So that when she tries to pray, all she sees is man. Hence, rather than assuming the rattan by which the woman is punished, Shug becomes the catalyst for her fellow woman's transformation.

\subsubsection{Celie vs. Shug}

After a long time of being insecure, a behaviour which presumably demonstrates her negative self-evaluation and self-rejection, Celie becomes strengthened, and the most significant catalyst or mechanism in her transformation is her love for Shug who teaches her the new meaning to life and the approach to overcome the stereotypes accorded her by patriarchy. Shug, who is supposed to oppose Celie rather becomes the catalyst to her growth and empowerment and she tells Celie:

Man corrupt everything, say Shug. He on your box of grits, in your head, and all over the radio. He try to make you think he everywhere. Soon as you think he everywhere, you think he God. But he ain't. Whenever you trying to pray, and man plop himself on the other end of it, tell him to git lost, say Shug. Conjure up flowers, wind, water, a big rock (The Color Purple, p.179).

She tells Celie that when man sticks out when Celie is praying, she should tell him to disappear- 'git lost' (The color purple, p.179). She, with the help of Shug, transforms and renews her mind immediately she changes the way she thinks about the man. Celie's transformation comes when she learns to love her husband's mistress, whom she has seen as a threat to her marriage at first. Generally, Walker and Angelou's works function as aspects of Black history and become firmly rooted in the network of the theme female/female friendship. Moreover, both texts show a development in the womanist process Walker and Angelou are evolving. For instance, the two novels portray the 
woman as a victor and heroine in a man's world through the help of other women. We also see Marguerite versus Mrs. Flowers who serves as her stimulant to her transformation.

Marguerite's and Celie's lot is pathetic and complex and amply illustrates the American situation of the treble oppression of the Black woman. Albert describes Celie thus, "You black, you pore, you ugly, you a woman. Goddam, he say, you nothing at all”. This displays how the man views the woman. Albert describes Celie as, first, black, poor, ugly and a woman. Albert in this context represents patriarchy- the man's world.

But all that changes when Celie, who could barely hit a child out of fear and naivety, becomes strong physically and emotionally through her friendship with Shug Avery as she asserts:

I stop the little trembling that started when I saw her coming. I ain’t never struck a living thing, I say, oh, when I was at home. I tap the little ones on the behind to make 'em behave, but not hard enough to hurt (The Color Purple, pp.46-47).

\subsubsection{Celie vs. Nettie}

Another instrument of her strength is her sister, Nettie. Celie finds strength when her sister writes to her to fight back. This is illustrated thus:

Dear Celie,

You've got to fight and get away from Albert. He ain’t no good. When I left you all's house, walking, he followed me on his horse. When we was well out of sight of the house he caught up with me and started trying to talk. You know how he do, You sure is looking fine, Miss Nettie, and stuff like that. I tried to ignore him and walk faster, but my bundles was heavy and the sun was hot. After while I had to rest, and that's when he got down from his horse and started to try to kiss me, and drag me back in the woods. Well, I started to fight him, and with God's help, I hurt him bad enough to make him let me alone. But he was some mad. He said because of what I'd done I'd never hear from you again, and you would never hear from me. I was so mad myself I was shaking. Anyhow, I got a ride into town on somebody's wagon....

love,

Nettie (The Color Purple, p.119)

The letter above narrates Nettie's encounter with her sister, Celie's husband. Nettie's opening speech urges Celie to fight Albert. Since she is able to overcome his sexual harassment, Celie can also fight him to get away. Like most African Americans, Celie takes her problems to God but she feels God does not understand all her predicaments that God is just like every other man who does not care about a coloured woman's dilemma. She deliberately takes a mental flight by telling God all she has been through but she later finds victory rather in her letters to her sister, Nettie. As seen below:

Dear Nettie,

I don't write to God no more, I write to you. What happen to God? ast Shug. Who that? I say. She look at me serious. Big a devil as you is, I say you not worried bout God, surely. What God do for me? I ast. She say, Celie! Like she shock. He gave you life, good health, and a good woman that love you to death. Yeah, I say, and he give me a lynched daddy, a crazy mama, a lowdown dog of a step pa and a sister I probably won't ever see again. Anyhow, I say, the God I been praying and writing to is a man. And act just like the other mens I know. Trifling, forgetful and lowdown. She say, miss Celie, You better hush. God might hear you. Let 'im hear me, I say. if he ever listened to poor colored women the world would be a different place, I can tell you.... Amen. (p.175)

Celie moves from being a terrorized, silenced or hushed, victim of rape and one who looks for a miracle and writes to God, to a woman who draws strength and authority both to live her life and to tell others about it, a strength that the reader of her letters realizes long before Celie herself does. Celie is a naïve woman, who finds, rediscovers and reconstructs her identity in the process of time from her love for other women, Shug, Sofia and her sister, Nettie.

When she later learns to write to her sister, Celie redefines her own concept of the world as a place of stars, trees, and people. But before then, Celie's letters demonstrate her courage, adaptation, resourcefulness and compassion, even when she sees nothing in herself except ugliness, emptiness, poverty, ignorance, weakness and insignificance.

Nettie, on the other hand, has not allowed herself to be an embarrassment to her family and relations. Her language is the kind some scholar describes as loud, emasculating and obstinate. She remains assertive and internally strong. 
This is articulated in her letter below:

Dearest Celie,

Just when I think I've learned to live with the heat, the constant dampness even steaminess of my clothes, the swampiness under my arms and between my legs, my friend comes. And cramps and aches and pain- but I must still keep going as if nothing is happening, or be an embarrassment to Samuel, the children and myself. (The Color Purple, p.195)

From the foregoing, the imageries deployed by Nettie to describe her situation to her sister, Celie are suggestive. Images of nature such as, dampness, steaminess, swampiness, etc. are all used as metaphors for high temperature, anxiety and lifelessness which indicate Nettie's problems in life, yet she refuses to give in, for the sakes of those she loves. Nettie uses these physical/natural images to depict the psychological by describing heat and relating that to hitches she experiences. Nettie also persuades Celie to fight for her survival. Celie as a naïve character trembles at anything, and is even intimidated by her step-children. As she writes to God, she explains her sister's counsel for her:

Mr. - children all bright but they mean. They say Celie, I want dis. Celie, I want dat. Our Mama let us have it.... Don't let them run over you, Nettie say. You got to let them know who got the upper hand. They got it I say. But she keep on. You got to fight. You got to fight. But I don’t know how to fight.

All I know how to do is stay alive.(The Color Purple, pp.25:26)

Celie feels that staying alive is enough rather than to fight back, especially in a male dominated society like hers where there is intimidation, terrorism and tyranny. She becomes an accommodationist just to stay alive. But Nettie, who is more assertive and strong-willed, urges her to fight back, as she says it repeatedly. Mr.- even beats her for 'looking at [a] boy' in church. On this occasion, Celie thinks she may have got something in her eye, as she did not wink at any boy. She added that the reason she does not look at men but looks at women is that she is scared of the men and laments, "He beat me today cause he say I winked at boy in church. I may have got something in my eye but I didn't wink. I don't even look at mens. That is the truth. I look at women, tho, cause I'm not scared of them” (The Color Purple, p.15).

This is a typical instance of male-on-female oppression the Black woman experiences. Celie does not look at men young or old, in order to avoid being beaten up by her husband, Mr. Albert and so she claims not to look at men partly because she is terrified by them, and also because of Mr. Albert's ill treatment.

From the passage above, Celie, sees Mr. — 's children as intelligent but mean, and so she feels panicky and gives in so easily to their irrational demands, thereby allowing herself to be oppressed by people even younger than her age.

The texts portray the idiosyncrasies of an unassertive and unassuming Black woman who has been a victim of patriarchy, and whose philosophy in life is 'do not fight back in order to stay alive'. Celie tells us about Nettie's piece of advice to her as Nettie persuades her, 'You got to fight them, Celie she say. I can't do it for you. You got to fight for yourself'. Celie expresses Nettie’s resilience thus, 'She fight, she run away. What good it do? I don't fight, I stay where I'm told. But I'm alive' (The Color Purple, p.29). This discourse is a gender-centered category in which one gender, the female, becomes the sufferer of the male gender but the female asserts herself by fighting and running away.

Nettie is that black woman who believes that 'she who fights and runs away lives to fight another day', hence her resilience. Celie is a compliant and an unassuming woman until other woman such as Shug, Nettie and Sofia help her to celebrate her God-given abilities as a black woman.

\subsubsection{Celie vs. Sofia}

Sofia also tells Celie that she has to fight all the males in her life in order to survive. The sentences in (i) - (v) from The Color Purple,(p.46) depict her assertiveness.

(i) All my life I had to fight

(ii) I had to fight my daddy

(iii) I had to fight my brothers

(iv) I had to my cousins and my uncles

(v) A girl child ain't safe in the family of men

These sentences flaunt the exertion of a self-assured woman who feels that the female gender is vulnerable and at risk in a world dominated by men. Sofia expressly listed the people she fights by repeatedly using the pronoun $I$ 
which means that she has to fight them, all by herself. In (i) she opens up with 'all my life' which also illustrates her effort in fighting the man. And then in (ii), (iii) and (iv) she enumerates the personality of the people she fights. All of which are with a +male gender identity. Let us consider the semantic features that buttress the fact that the personalities underlined are symbols of the male gender.

\section{Gendered-self Categorization}

The table in Figure1 demonstrates the gender identity of the underlined words/group in (i) - (v) using semantic features or componential analysis. I use plus (+) to show where a feature is present and minus (-) where feature is absent. See the table 1 for more explanation.

Table 1: Semantic Features for Gender Categorization

\begin{tabular}{|c|c|c|c|c|}
\hline Identity type & Male & Female & Human & Category \\
\hline & & & & $\begin{array}{l}\text { Used for fathers or one recognized } \\
\text { as a father, that is an adult male }\end{array}$ \\
\hline Daddy & + & - & + & \\
\hline Brothers & + & - & + & $\begin{array}{l}\text { Used for males of same parents } \\
\text { and other male relations }\end{array}$ \\
\hline & & & & $\begin{array}{l}\text { Used for uncle's and aunt's } \\
\text { children, male or female(gender } \\
\text { neutral) }\end{array}$ \\
\hline Cousins & $-/+$ & $-/+$ & + & \\
\hline Uncles & + & - & + & $\begin{array}{l}\text { Used for father's and mother's } \\
\text { brother }\end{array}$ \\
\hline Girl child & - & + & + & A young female \\
\hline
\end{tabular}

The table 1 shows daddy, brothers, uncles as possessing +male, but cousins with +/- male. Of course it is true that cousin is gender neutral and it is only in context that one can decipher or surmise the person's gender. Therefore, the context invoked by Sofia in the sentences in (i) - (iv) is that which fights only the male gender and the sentence in (v) explains it by concluding with the word men. In sum, our analysis in the table 1 shows the sentences as gender-doing categories found in the novel, The Color Purple where one gender, especially the female, strives for survival by fighting.

Unlike these female characters, Sofia, Nettie and Shug in the texts, The Color Purple, Celie is a hushed female who do not have the will power to hurt anybody. Her explanation in (1) sufficed this stance as she asserts:

1) I tap the little ones on the behind to make 'em behave , but not hard enough to hurt (TCP, p.47).

'I' and 'ones' in (1) are Given elements that the reader preempts. The reader knows who is talking (Celie), and who is talked about (theme), that is, Albert's Children. But the New information here is what the speaker does to the theme, 'little ones'. Thus, the verb, tap is used as the process which indicates where the action takes place. That is, tapping the little ones' behind (back), but 'not hard enough to hurt' (rheme).

Language is a means of representing the world, real or imaginary. It encodes human experiences and reality. The language of the novels shows the formative roles in which human experiences are based and at the same time, it functions as part of the reality which it sets out to represent or encode. Looking more closely at the linguistic representation in The Color Purple and The Caged Bird, I examine texts using the terms Process and Participant to describe events, things and characters in the texts. Process in systemic linguistics centres on that part of the clause that is realized by the Verbal Group, and can also be regarded as the 'goings-on' as represented in the clause. Participants, on the other hand, are the entries involved in the Process. So, in the texts in (iv)- (vi), I describe the Participants and the Process in the novels to show how different codes interact.

2) My little girl/she/look up and [...] sort of frown (TCP, p.22)

3) I am sure Albert is still the only one to take mail out of the box (TCP, p.112) 
4) We are coming home before the end of another year (TCP, p.112)

The structure in (2) uses she as a pronoun in apposition to my little girl, and the conjunctive clause applies an elliptical subject to avoid the repetition of the pronoun she. The underlined words in (3) and (4) indicate the Participants in the discourse. Nettie being the narrator uses the pronoun $I$, and Albert is the theme for whom one refers. So, Albert becomes the Actor, the performer of the action, described by the Process to take, a to-infinitive, and my label for mail in the clause is the Goal in which the Process, to take acts. In (2), the elliptical subject is the Actor (the performer), my little girl and she, who performs the action look and frown all of which are Material Process. We in (4) stands for Nettie, who is the speaker, Celie's children: Olivia and Adam who were adopted by Samuel and Corrine, a husband and wife who are Missionaries of the American and African Missionary Society. During their sojourn in Africa, Corrine dies and Nettie becomes Samuel's wife. Thus, we as used in the letter is a referent for Nettie, Olivia, Adam and Samuel.

Celie's unassuming female quality is made obvious when she advises Sofia to stay with her husband Harpo. Celie never fight back attitude follows her around, it becomes like an aura or a presence that robs off on other around. But Sofia's never give-in quality also makes her outstanding, as she opts out of her marriage. In the text, Harpo beats Sofia and assertive Sofia fights back and later emancipates. The text in (5) reveals Celie's attempt to make Sofia remain, she says:

$$
\text { S-aux } \quad \mathrm{C} \quad \mathrm{P} \quad \mathrm{C}
$$

5) $/ / / \mathrm{He} / Ø /$ your husband, I say. [...]/Got to stay/ with him///(TCP, p.67)

One of the unique characters of Ebonics is in its elliptical subject. Most times in Ebonics, subjects are deleted from a string of thought. For instance, the text in (5b) has an elliptical Subject, you, the Actor; which is not expressed in the conjunctive clause but is understood to be referring to Sofia who is addressed. It is a straightforward case of ellipsis as we know what the referent of the 'gap' is, that is you. You, here refers to Sofia for whom Celie addresses.

From the epistolary realism, The Color Purple, Sofia is an obstinate Black woman who emancipates from the old order of the patriarchal system as she opts out of her marriage - that, which the feminists describe as 'a domestic prison'. She renounces the traditional way of being a Black woman, who gets married, has children and carters for their needs, and who is beaten by the man when she transgresses. She becomes brave as she fights for her survival. In the text in (5b), Celie, who is a docile and unassertive, urges Sofia to stay with her husband, Harpo. She says, 'He your husband.... [...]Got to stay with him'.

In a nutshell, the language of characters like Sofia, Shug Avery and Nettie, and Marguerite in the texts: The Color Purple and I Know Why the Caged Bird Sings portrays a total shift from the old unassuming attitude of the female in Black American society to the assertive, resilient and bold new women who see male hegemony as oppressive, and that which must be fought against.

\section{Conclusion}

In conclusion, most feminist critics explore the tensions and ambiguities inherent in both Angelou's and Walker's novels and attempt to define a feminist position and at the same time subscribe to what sounds like a stereotyped view of femininity and womanhood. However, the point reestablished in this paper is that, individuals are the architects of their lives; that though the society prescribes roles each gender should operate, individuals, the females in particular have the rights to reconstruct their identities in the society that they are part of, reconstructing identity either as assertive women or naïve females.

Using epistolary style, Walker is able to have her major character, Celie express the impact of male-oppression on her spirit, and the text also portrays Celie internal strength and victory at the end of the text. Walker's choice of a southern Black American woman as her protagonist is predicated upon the fact that, all women in the south had collectively experienced male oppression in one way or the other; an oppression that elicits from the women a willingness to reject convention and to hold on to that which is difficult by asserting self. The text, The Color Purple, as I pointed out earlier, is an epistolary realism that portrays the psychological growth of the main character, Celie, who represents the $19^{\text {th }}$ century Black woman in America.

Angelou, on the other hand, narrates her experiences in the south. She explains that, life in the south is usually negative as it is characterized by drought, floods, lynching and deaths (I Know Why the Caged Bird Sings, p.88). She recounts her experiences as a young Black girl growing up in Stamps. Her journeys in the text not only show her physical movements but also her psychological transformation that makes her move from an inexperienced young 
Black girl to a tough woman in the end. Both texts show the movements of two Black women who moved from naivety to self actualization and realization. From the exploration of the novels, I accentuate the position that individuals can reconstruct their self identities contrary to societal ascriptions.

\section{References}

Andersen, M. L., \& Taylor, H. F. (2005). Sociology: The Essentials (3rd ed.). Belmont: Thomson Wadsworth.

Angelou, M. (1970). I Know Why The Caged Bird Sings. New York: Random House.

Baker, Jr. H. (1971). Black Literature in America. New York: McGraw Hill.

Bernstein, B. (1971). Class, Codes and Control 3 Volumes. London: Routledge and Kegan Paul. http://dx.doi.org/10.4324/9780203014035

Blackwell, J. (1991). The Black Community: Diversity and Unity ( $3^{\text {rd }}$ Ed.). New York: HarperCollins.

Butler, J. (1990). Gender Trouble: Feminism and The Subversion of Identity. London: Routledge.

Butterfield, S. (1974). Black Autobiography in America. Amherst: University of Massachusetts Press.

Cameron, D. (2005a). Language, Gender and Sexuality: Current Issues and New Directions. Applied Linguistic, 26, 482-502. http://dx.doi.org/10.1093/applin/ami027

Cameron, D., \& Kulick, D. (2003). Language and Sexuality. Cambridge: Cambridge University Press. http://dx.doi.org/10.1017/CBO9780511791178

Chigbo, M. A. (2000). The Early History of America and Inter-group Relations among The Settlers. Currents in Early American Literature. A. A. Akpuda. Ed. 24

Collins, P. H. (1987). The Meaning of Motherhood in Black Culture. Sage: A Scholarly Journal on Black Women, 4, 3-10.

Davis, A. (1981). Women, Race and Class. New York: Random House.

Demetrakopoulus, S. (1980). The Metaphysics of Materialinearism in Women's Autobiography: Studies of Mead's Blackberry Writer, Hellman's Pentimento, Angelou's I Know Why the Caged Bird Sings, and Kingston's The Woman Warrior. Women's Autobiography: Essays in Criticism. Ed. Estelle Jelinek, Bloomington: Indiana University Press.

Eckert, P., \& McConnell-Ginet, S. (1995). Constructing Meaning, Constructing Selves: Snapshots of Language, Gender and Class From Belten High. In K. Hall and M. Bucholtz. Eds. Gender Articulated: Language and The Socially Constructed Self(p469-508). New York: Routledge.

Eckert, P., \& McConnell-Ginet, S. (2003). Language and Gender. Cambridge: Cambridge University Press. http://dx.doi.org/10.1017/CBO9780511791147

Ehrlich, S. (2004). Language and gender. In A. Davis. and C. Elder Eds. The Handbook of Applied Linguistics(Pp323-330). Oxford: Blackwell. http://dx.doi.org/10.1002/9780470757000.ch12

Eko, E. (2005). Struggle and Survival: Strategic Parallels in African and African American Literary Experiences. Calabar: University of Calabar Press.

Fairclough, N. (1995). Critical discourse analysis: the critical study of language. London: Longman.

Feldman, R. S. (1996). Understanding Psychology. Boston: McGraw-Hill.

Fowler, R. (1978). Studying Literature as Language. In D. O. Oaks. Ed. Linguistics at Work: A Reader of Applications(p553-563). Orlando: Harcourt Brace.

Fowler, R. (1981). Literature as Social Discourse. London: Batford.

Fox-Genovese, E. (1990). Myth and History: Discourse of Origins in Zora Neale Hurston and Maya Angelou. Black American Literature Forum, 24(2), 221-235. http://dx.doi.org/10.2307/3041705

Franklin, J. H., \& Moss, A. A. (1988). From Slavery to Freedom: A History of Negroes Americans. New York: McGraw Hill.

Gardner, R. (2004). Conversation Analysis. In A. Davis and C. Elder Eds. The Handbook of Applied Linguistics(p281-284). Oxford: Blackwell. http://dx.doi.org/10.1002/9780470757000.ch10 
Gilroy, P. (1993). The Black Atlantic: Modernity and Double Consciousness. New York: Verso.

Grier, W. G., \& Cobbs, P. (1968). Black Rage. New York: Vintage Books.

Gupta, G. R. (2000). Gender, Sexuality and HIV/AIDS: The What, The Why and The How. Being a Plenary Address at XIIIth International Centre for Research on Women (ICRW), July 12, 2000.

Harding, S. (1991). Whose Science? Whose Knowledge? Thinking From Women's Lives. Ithaca, NY: Cornell University Press.

Hillmann, M. C. (1992). I know Why The Caged Bird Sings. In Frank Magill. Ed. Masterpieces of African American literature(p214-220). New York: HarperCollins.

Joseph, J. E. (2004). Language and Identity: National, Ethnic, Religious. New York: Palgrave Macmillan.

Killam, D., \& Rowe, R. (Eds.) (2000). The Companion to African Literature. Oxford: James Currey Ltd.

Lunsford, A. A., \& Ruszkiewicz, J. J. (2004). The Presence of Others: Voices and Images that Call for Response (4th ed.). Boston: Bedford/ St. Martin's.

Lyons, J. (1985). Language and Literature: An Introduction. London: Cambridge University Press.

Matthews, G. (1992). The Rise of The Public Woman: Woman's Power and Woman's Place in The United States, 1630-1970. Oxford: Oxford University Press.

McPherson, D. (1990). Order out of Chaos. The Autobiographical Works of Maya Angelou. New York: Peter Lang.

Mey, J. L. (2001). Pragmatics: An Introduction (2nd Ed.). Oxford: Blackwell.

Mills, S. (1995). Feminist Stylistics. London: Routledge.

Ottoh, B. O. (2007). A Lexico-semantic Analysis of Alice Walker's The Color Purple. BA Project Dept of English and Literary Studies. University of Calabar. 8+63pp.

Ottoh, B. O., \& Agede, J. I. (2009). Feminism Versus Patriarchism: A Philosophical Appraisal From a Complementary Approach. The Quill, 3(4), 22-28.

Ottoh, B. O. (2012). Language and Identity in Alice Walker's The Color Purple and Maya Angelou's I know Why The Caged Bird Sings. MA Project Dept of English. University of Ibadan. 6+124pp.

Palmer, F. R. (1996). Semantics. Cambridge: Cambridge University Press.

Paltridge, B. (2006). Discourse Analysis. London: Continuum.

Pryse, M., \& Spillers, H. J. (1985). Conjuring Black Women, Fiction and Literary Tradition. Bloomington: Indiana University Press.

Rickford, J. R., \& Rickford R. J. (2000). Spoken Soul: The Story of Black English. New York: John Wiley and Sons.

Riley, G. (1987). Inventing the American Woman: A Perspective on Women's History. Illinois: Harlan Davidson

Taylor, D. (1992). The Color Purple. Masterpieces of African American literature. Frank Magill. Ed. New York: HarperCollins. 170-110

Thornborrow, J., \& Wareing, S. (1998). Patterns in Language: An Introduction to Language and Style. London: Routledge.

Unger, R. M. (1987). Social Theory: Its Situation and Its Task. Cambridge: Cambridge University Press.

Walker, A. (1982). The Color Purple. New York: Pocket Books.

Wood, J. T. (1999). Gendered Lives: Communication, Gender, and Culture (3rd ed.). Belmont: Wadsworth Publishing Company.

Maya Angelou's Biography. (2011). In Achievement, encyclopedia. Retrieved February 20, 2011 from http//:www.achievement.org/doi/autodoc/page/angobio-1

List of Feminist Literature. (2013). In Wikipedia, the free encyclopedia. Retrieved May 29, 2013 from http://en.wikipedia.org/wiki/Feminist_literature 